\title{
Regulation of CRF, POMC and MC4R Gene Expression after Electrical Foot Shock Stress in the Rat Amygdala and Hypothalamus
}

\author{
Yoshiaki YAMANO ${ }^{1)}$, Masanobu YOSHIOKA ${ }^{1)}$, Yoshihisa TODA ${ }^{2)}$, Yuichi OSHIDA ${ }^{2)}$, Shigeyuki CHAKI ${ }^{2)}$, \\ Kaori HAMAMOTO $^{1)}$ and Isao MORISHIMA ${ }^{1)}$ \\ ${ }^{1)}$ Department of Biochemistry and Biotechnology, Faculty of Agriculture, Tottori University, Tottori 680-8553 and ${ }^{21}$ Medicinal \\ Pharmacology Laboratory, Medicinal Research Laboratories, Taisho Pharmaceutical Co., Ltd., Saitama 331-9530, Japan
}

(Received 9 April 2004/Accepted 14 June 2004)

ABSTRACT. We investigated the effects of electrical foot shock stress on the melanocortin signaling cascade and the hypothalamus-pituitary-adrenal (HPA) system by observing levels of mRNA expression of corticotropin releasing factor (CRF), pro-opiomelanocortin (POMC), and melanocortin receptor subtype 4 (MC4R) in the rat amygdala and hypothalamus. When rats were exposed to electrical shock for $0.5 \mathrm{hr}$ or $1 \mathrm{hr}$, plasma ACTH and corticosterone concentrations increased, indicating stress. The rats were then sacrificed to obtain RNA preparations from the brain tissue. In the amygdala, the expression of MC4R and POMC mRNA as well as CRF mRNA was significantly increased by electrical foot shock stress. In the hypothalamus, MC4R and POMC mRNA increased, but CRF mRNA remained unchanged. The duration of increased gene expression of MC4R and POMC in the amygdala was more sustained than in the hypothalamus. These results have provided the first evidence that exposure to stress increases expression of the MC4R system in the amygdala and hypothalamus.

KEY WORDS: amygdala, electrical stress, gene expression, hypothalamus, melanocortin receptor subtype 4.

J. Vet. Med. Sci. 66(11): 1323-1327, 2004

It is well known that stress responses are mediated by stimulation of the hypothalamus-pituitary-adrenal (HPA) axis, and that glucocorticoids are finally secreted from the adrenal cortex to guard against stress disorders. When animals are subjected to stress, corticotropin releasing factor (CRF) is secreted from the hypothalamus [8]. CRF secretion triggers stress response and exerts its effects by binding to a specific receptor, $\mathrm{CRF}$ receptor type 1 (CRF-R1), which is expressed in the anterior pituitary. In addition to CRF, brain melanocortins are involved in stress responses.

Reported to be involved in anxiogenic behavior in laboratory animals, melanocortins stimulate the HPA axis $[6,11$, 25]. Melanocortins are a group of protein hormones derived by post-translational cleavage of the pro-opiomelanocortin (POMC). The melanocortin stimulating hormones (MSHs) include $\alpha$-melanocyte stimulating hormone ( $\alpha$-MSH), $\beta$ melanocyte stimulating hormone $(\beta$-MSH), $\gamma$-melanocyte stimulating hormone $(\gamma-\mathrm{MSH})$ and adrenocorticotropic hormone (ACTH). ACTH stimulates the secretion of glucocorticoids from the adrenal cortex, and $\alpha$-MSH stimulates melanin formation in the melanocytes. To date, five types of melanocortin receptors, subtype 1 to subtype 5 (MC1R to MC5R), all belonging to the G-protein-coupled receptor (GPCR) superfamily, and positively coupled to adenylate cyclase, have been reported [26]. Among them, MC4R has been of particular interest in terms of the relationship to regulation of food intake and energy expenditure [14]. In addition to its role in feeding behavior, several studies indicate that MC4R plays an important role in stress response and in the regulation of emotional behavior. MC4R occurs throughout the brain, including the limbic system [19].

Stimulation of MC4R resulted in excessive grooming behavior [1] as well as activation of the HPA axis [25], whereas MC4R antagonists prevent MC4 agonist- and novelty-induced grooming behavior [1]. Likewise, MC4R antagonists attenuate stress-induced anorexia [4, 25] as well as anxiogenic behavior $[4,5]$ in rodents. Harris, R.B. et al. reported that mice overexpressing the Agouti-related protein (AgRP), an inverse agonist of MC4R, displayed heightened responsiveness to stress [12]. These results suggest a role for the MC4R cascade in stress response, but regulation of the expression of MC4R and its endogenous ligand, POMC, in the brain by stress is poorly understood. The amygdala and the hypothalamus are brain structures that are deeply involved in stress response and the regulation of the HPA axis [15, 22]. Moreover, i.c.v. administration of an MC4R agonist increased Fos-like immunoreactivity in the paraventricular nucleus (PVN) of the hypothalamus and in the central nucleus of the amygdala [3], indicating that these brain areas are the target structures of the MC4R system. In this report, we investigated the effects of electrical foot shock stress on fluctuations in CRF, POMC and MC4R expression in the amygdala and the hypothalamus, and discuss the relationship between the HPA system and the melanocortinergic system [13]. Electrical foot stress is usually used as a stressor in animal models such as conditioned fear stress and learned helplessness. It was reported that an MC4 receptor antagonist was effective in learned helplessness [4]. Therefore, in the present study, we employed electrical foot shock stress to investigate the change in the expression level of POMC and MC4R.

\section{MATERIALS AND METHODS}

Animals and application of electrical foot shock stress: Male SD rats, weighing 200-220 g (Charles River, Yoko- 
hama, Japan), were maintained under a 12:12 hr light/dark cycle with lights on at 7:00 a.m. in a temperature- and humidity-controlled holding room. Food and water were made available ad libitum. All studies were reviewed by the Taisho Pharmaceutical Co., Ltd. Animal Care Committee, and met the Japanese Experimental Animal Research Association Standards, as defined in the Guidelines for Animal Experiments (1987).

The rats were placed in a transparent plastic container (communication box, $81 \mathrm{~cm}$ long, $61 \mathrm{~cm}$ wide and $45 \mathrm{~cm}$ high) divided into 12 separate areas (each $20 \mathrm{~cm}$ square). Stainless grids placed at the bottom of the container were connected to electrodes to make it possible to apply an electric current from a Generator/Scrambler (Astec Co., Ltd., Japan). Electrical stress was applied for $5 \mathrm{sec}$ every $30 \mathrm{sec}$ over a period of $0.5 \mathrm{hr}$ or $1 \mathrm{hr}$. The electric current was 2.5 $\mathrm{mA}$. After the application of stress, rats were sacrificed by decapitation, blood was collected for ACTH and corticosterone analysis, and each brain region was removed for RNA preparation.

RNA isolation and plasma ACTH and corticosterone analysis: Total RNA was prepared from rat brain tissues with ISOGEN (Nippon Gene Co., Ltd., Japan) by the method recommended by the manufacturer. RNA concentrations were determined by the photospectrometric method. The purity and integrity of the RNA was confirmed by electrophoresis on a $1 \%$ agarose gel that contained $2.2 \mathrm{M}$ formaldehyde.

Plasma corticosterone concentrations were determined by Coat-A-Count, Rat Corticosterone (Diagonostic Products Corporation, CA, U.S.A.) with the rat ${ }^{125} \mathrm{I}$-corticosterone. ACTH concentrations were determined by ACTH immunoradiometric assay (Mitsubishi Chemical Co., Ltd., Japan), with the ${ }^{125}$ I-anti-human ACTH antibody, according to the procedure recommended by the manufacturer.

Probe preparation: Each probe DNA was synthesized and cloned by the RT-PCR method, with a QIAGEN OneStep RT-PCR Kit and a QIAGEN PCR Cloning Kit (QIAGEN Japan, Tokyo). Total RNA of SD rats, which was prepared from hypothalamus, was used as an RT template, and the cDNA generated was used for a PCR template. PCR primers were synthesized following the reported DNA sequences. As rat MC4R cDNA sequence is deposited in the DNA data bank as an accession number, NM_013099 [10], we synthesized the probe DNA with the following primers. The upstream primer sequence was GCAGG AAGAT GAACT CCACC and the downstream primer sequence was CCCAC TTAAT ACCTG CCAGG.

The rat POMC sequence is deposited as an accession number, AF510391, by Takamori, Y. and Yamada, H. (unpublished results).

The upstream primer sequence is ATGCC GAGAT TCTGC TACAG and the downstream primer sequence is TCACT GGCCC TTCTT GTGCG. The rat CRF sequence is deposited as an accession number, X03036 [17]. The upstream primer sequence is GAGAA AGGGG AAAGG CAAAG and the downstream primer sequence is CTGTA

\section{CATCT TCTAT GCTTC.}

The expected amplified cDNA fragments are as follows: rat MC4R is $820 \mathrm{bp}$, rat POMC 708 bp, and rat CRF 720 bp. The amplified DNA fragments were ligated with pDrive Cloning Vector and transformed into QIAGEN EZ competent cells. The amplified cDNA sequence was determined by the dideoxy chain termination method, with a DNA sequencer (ABI 3100 Genetic Analyzer). Rat $\beta$-actin cDNA [21] was used as an expression standard.

Northern blot analysis: Total RNA $(10 \mu \mathrm{g})$ was electrophoresed in a $1 \%$ agarose gel containing formaldehyde and transferred to a nylon membrane Hybond $\mathrm{N}^{+}$(Amersham Biosciences, U.S.A.). Rat cDNAs for MC4R, POMC, CRF and $\beta$-actin were labeled with $\left[\alpha-{ }^{32} \mathrm{P}\right] \mathrm{dCTP}$ with a random primer labeling system (Amersham Biosciences, U.S.A.). Hybridization was performed in a mixture consisting of 0.5 M sodium phosphate buffer ( $\mathrm{pH} 7.2), 1 \mathrm{mM}$ EDTA $(\mathrm{pH}$ 8.0), 7\% sodium dodesyl sulfate (SDS), containing $500 \mathrm{ng} /$ $\mathrm{m} l$ denatured herring sperm DNA, and the labeled probe DNA, at $55^{\circ} \mathrm{C}$ for $24 \mathrm{hr}$. The membrane was finally washed twice in a buffer consisting of $0.1 \times \mathrm{SSC}$ with $0.1 \% \mathrm{SDS}$ at $65^{\circ} \mathrm{C}$ for $5 \mathrm{~min}$, and radioactivity was measured with a FLA5000 Fuji fluoro-image analyzer (Fuji Film Co., Ltd., Japan).

Data analysis: Results are presented as means $\pm \mathrm{SE}$ throughout. Statistical significance was determined by Student's $t$-test.

\section{RESULTS AND DISCUSSION}

After exposure to electrical foot stress for $0.5 \mathrm{hr}$ or $1 \mathrm{hr}$, SD rats had noticeably increased plasma ACTH and corticosterone concentrations. Plasma ACTH concentrations increased by 7.4 fold after $0.5 \mathrm{hr}$ of stress, and by 2.7 fold after $1 \mathrm{hr}$ of stress, compared to the nonstressed control group. Corticosterone concentrations increased by 6.0 fold after $0.5 \mathrm{hr}$ stress, and by 3.9 fold after $1 \mathrm{hr}$ stress, compared to the nonstressed control group (Table 1). These results clearly show that the stress conditions imposed in this study noticeably activated the HPA axis in the rats. After stress exposure for $0.5 \mathrm{hr}$, corticosterone and ACTH concentrations in plasma increased to the maximal levels, but these concentrations declined after the $1 \mathrm{hr}$ stress, presumably due to a negative feedback mechanism.

To clarify the relationship between stress and the neural melanocortinergic system, we examined the expression of

Table 1. Concentrations of ACTH and corticosterone after $0.5 \mathrm{hr}$ and $1 \mathrm{hr}$ electrical stress in rats

\begin{tabular}{cccc}
\hline & ACTH & & corticosterone \\
\cline { 2 - 2 } & $p \mathrm{~g} / \mathrm{m} l$ & & $n \mathrm{~g} / \mathrm{m} l$ \\
\hline control & $16.7 \pm 2.2$ & & $64.4 \pm 29.7$ \\
$0.5 \mathrm{hr}$ & $123 \pm 32.5^{* *}$ & & $385 \pm 49.4^{* *}$ \\
$1 \mathrm{hr}$ & $44.4 \pm 13.5^{* *}$ & & $252 \pm 40.9^{* *}$ \\
\hline
\end{tabular}

Data represent the mean \pm SE obtained from 6 animals. $* * \mathrm{p}<0.01$ versus control. 
(a)Amygdala

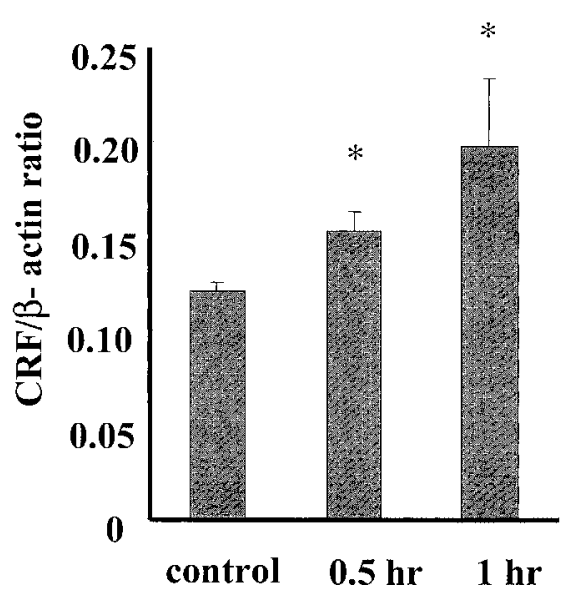

(b)Hypothalamus

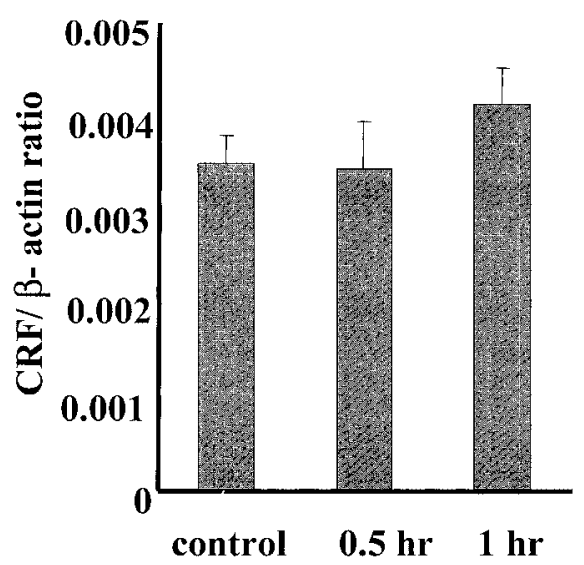

Fig. 1. Effects of electrical stress on CRF mRNA expression in the amygdala and the hypothalamus. Northern blotting was performed with $10 \mu \mathrm{g}$ of total RNA, prepared from (a) the amygdala, and (b) the hypothalamus of control animals, $0.5 \mathrm{hr}$ stressed animals $(0.5 \mathrm{hr})$, and $1 \mathrm{hr}$ stressed animals $(1 \mathrm{hr})$. mRNA expression was standardized with the intensity of $\beta$-actin. The vertical axis is relative radioactivity $(\mathrm{CRF} / \beta$-actin ratio). Each value represents the mean $\pm \mathrm{SE}(\mathrm{n}=5$, $\mathrm{P}<0.05$, versus control).

(a)Amygdala

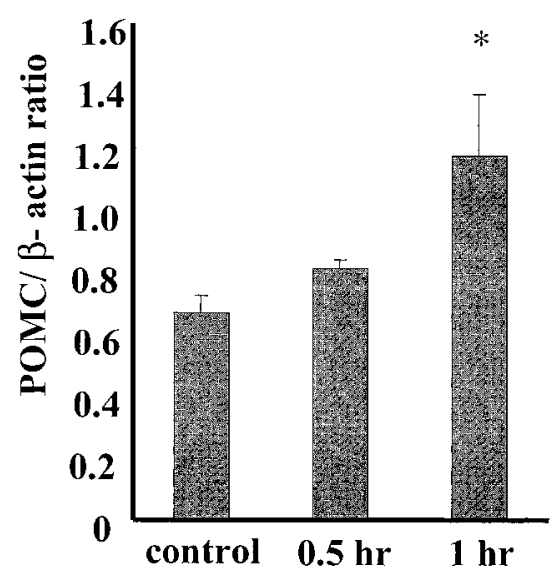

(b)Hypothalamus

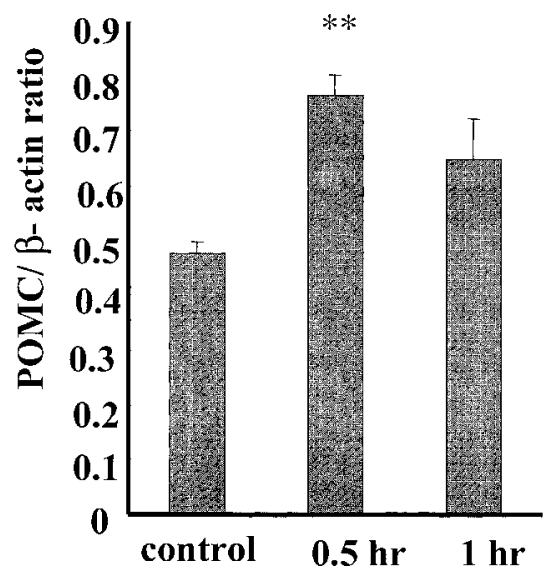

Fig. 2. Effects of electrical stress on POMC mRNA expression in the amygdala and the hypothalamus. Northern blotting was performed with $10 \mu \mathrm{g}$ of total RNA, prepared from (a) the amygdala, and (b) the hypothalamus of control animals, $0.5 \mathrm{hr}$ stressed animals $(0.5 \mathrm{hr})$, and $1 \mathrm{hr}$ stressed animals $(1 \mathrm{hr})$. The mRNA expression was standardized with the intensity of $\beta$-actin. The vertical axis is relative radioactivity (POMC/ $\beta$-actin ratio). Each value represents the mean $\pm \mathrm{SE}(\mathrm{n}=5, * \mathrm{P}<0.05, * * \mathrm{P}<0.01$ versus control).

MC4R and its endogenous ligand, POMC mRNA, in the amygdala and hypothalamus, both of which are brain regions deeply involved in stress response.

In the amygdala, electrical foot shock stress significantly increased CRF mRNA after $0.5 \mathrm{hr}$ or $1 \mathrm{hr}$ of foot shock stress (Fig. 1). Likewise, mRNA levels of POMC (Fig. 2) and MC4R (Fig. 3) were significantly increased, although the increase in POMC after $0.5 \mathrm{hr}$ was insignificant (Fig. 2). The amygdala plays a role in orchestrating various aspects of emotional output and fear-related behavior [7]. It has been reported that CRF expression and the release of CRF in the amygdala is rapidly increased by restraint stress $[16,18]$, and activation of the CRF system in the central nucleus of the amygdala is postulated to mediate the emotional effects 
(a)Amygdala

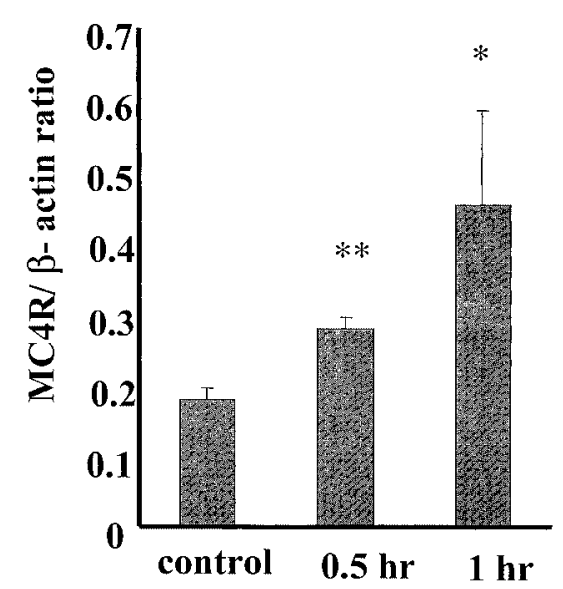

(b)Hypothalamus

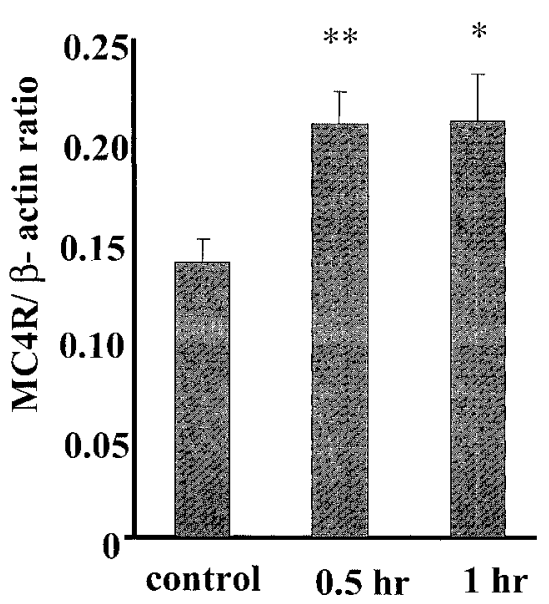

Fig. 3. Effects of electrical stress on MC4R mRNA expression in the amygdala and the hypothalamus. Northern blotting was performed with $10 \mu \mathrm{g}$ of total RNA, prepared from (a) the amygdala, and (b) the hypothalamus of control animals, $0.5 \mathrm{hr}$ stressed animals $(0.5 \mathrm{hr})$, and 1 hr stressed animals $(1 \mathrm{hr})$. The mRNA expression was standardized with the intensity of $\beta$ actin. The vertical axis is relative radioactivity $(\mathrm{MC} 4 \mathrm{R} / \beta$-actin ratio). Each value represents the mean $\pm \mathrm{SE}(\mathrm{n}=5, * \mathrm{P}<0.05, * * \mathrm{P}<0.01$ versus control).

of stress $[2,22]$. Although the conditions of stress in these studies differed, the present results are consistent with the earlier findings. Reports also indicate that MC4R mRNA is widely distributed in the amygdala, including the central nucleus [19], and suggest that an increase in POMC mRNA in the amygdala may be responsible for anxiety and aggression [16]. The noticeable increase in MC4R and POMC expression in the amygdala after stressful experience is interesting in terms of the possible role of the MC4R system in anxiety and stress-related behavior $[4,5]$.

In the hypothalamus, both POMC (Fig. 2) and MC4R (Fig. 3) mRNA expression increased significantly, but that of CRF remained unchanged (Fig. 1). The reason is unknown and should be elucidated, however several lines of evidence indicate that CRF mRNA in the PVN of the hypothalamus is noticeably increased by various types of stressors $[15,18]$. MC4R has been reported to be strongly expressed throughout the hypothalamus, including the PVN [19], which plays a pivotal role in the regulation of endocrine responses to stress such as HPA axis activation. There are several lines of evidence showing interactions between the melanocortinergic system and CRF in the hypothalamus. A double-labeling in situ hybridization study has shown that a subpopulation of CRF neurons in the PVN contains $\mathrm{MC} 4 \mathrm{R}$, concentrated in the ventromedial part of the parvicellular PVN [20]. $\alpha$-MSH enhances CRF release from hypothalamic explants [9]. Intracerebroventricular injection of $\alpha-\mathrm{MSH}$ and MT II, an MC4R agonist, increases CRF gene expression in the PVN, accompanied by increased plasma corticosterone. An MT II-induced increase in plasma corticosterone was attenuated by CRF receptor antagonists [20,
23]. In light of these findings and the present observations, it is conceivable that CRF may act as a downstream mediator of melanocortin signaling in the hypothalamus and that activation of the MC4R system during stress stimulates the HPA axis by enhancing the CRF system.

The rate of increase in MC4R and POMC gene expression is different in the amygdala and the hypothalamus. The increase in the amygdala featured a relatively slow onset after $1 \mathrm{hr}$ stress exposure compared to $0.5 \mathrm{hr}$, whereas alteration of gene expression reached a plateau (MC4R) or declined (POMC) (Figs. 2 and 3) in the hypothalamus. The time course of these gene expressions was similar to that of ACTH, which peaked at $0.5 \mathrm{hr}$ stress exposure, declining thereafter (Table 1). The MC4R system in the hypothalamus may be regulated via the negative feedback mechanism of increased corticosterone, as observed with CRF [15]. In contrast, the present findings suggest that the MC4R system in the amygdala may not be heavily influenced by the negative feedback mechanism.

In conclusion, the present results provide evidence that stress exposure activates the MC4R system in the amygdala and hypothalamus, and that activation of the MC4R system in these regions of the brain may be responsible, at least in part, for stress responses such as HPA axis activation and fear and anxiety. Further assessment and clarification of this hypothesis will require more detailed studies, including histochemical studies.

\section{REFERENCES}

1. Adan, R.A., Szklarczyk, A.W., Oosterom, J., Brakkee, J.H., 
Nijenhuis, W.A., Schaaper, W.M., Meloen, R.H. and Gispen, W.H. 1999. Characterization of melanocortin receptor ligands on cloned brain melanocortin receptors and on grooming behavior in the rat. Eur. J. Pharmacol. 378: 249-258.

2. Bakshi, V.P., Smith-Roe, S., Newman, S.M., Grigoriadis, D.E. and Kalin, N.H. 2002. Reduction of stress-induced behavior by antagonism of corticotropin-releasing hormone 2 (CRH2) receptors in lateral septum or CRH1 receptors in amygdala, $J$. Neurosci. 22: 2926-2935.

3. Benoit, S.C., Schwartz, M.W., Lachey, J.L., Hagan, M.M., Rushing, P.A., Blake, K.A., Yagaloff, K.A., Kurylko, G., Franco, L., Danhoo, W. and Seeley, R.J. 2000. A novel selective melanocortin-4 receptor agonist reduces food intake in rats and mice without producing aversive consequences. J. Neurosci. 20: 3442-3448.

4. Chaki, S., Hirota, S., Funakoshi, T., Suzuki, Y., Suetake, S., Okubo, T., Ishii, T., Nakazato, A. and Okuyama, S. 2003. Anxiolytic-like and antidepressant-like activities of MCL0129 (1[(S)-2-(4-fluorophenyl)-2-(4-isopropylpiperadin-1-yl)ethyl]-4[4-(2-methoxynaphthalen-1-yl)butyl]piperazine), a novel and potent nonpeptide antagonist of the melanocortin-4 receptor. $J$. Pharmacol. Exp. Ther. 304: 818-826.

5. Chaki, S., Ogawa, S., Toda, Y., Funakoshi, T. and Okuyama, S. 2003. Involvement of the melanocortin MC4 receptor in stress-related behavior in rodents. Eur. J. Pharmacol. 474: 96101.

6. Corda, M.G., Orlandi, M. and Fratta, W. 1990. Proconflict effect of ACTH1-24: interaction with benzodiazepines. Pharmacol. Biochem. Behav. 36: 631-634.

7. Davis, M. and Shi, C. 1999. The extended amygdala: are the central nucleus of the amygdala and the bed nucleus of the stria terminals differentially involved in fear versus anxiety? Ann. New York Acd. Sci. 877: 281-291.

8. de Costa, A.P., Ma, X., Ingram, C.D., Lightman, S.L. and Aguilera, G. 2001. Hypothalamic and amygdaloid corticotropinreleasing hormone (CRH) and CRH receptor-1 mRNA expression in the stress-hyporesponsive late pregnant and early lactating rat. Brain Res. Mol. Brain Res. 91: 119-130.

9. Dhillo, W.S., Small, C.J., Seal, L.J., Kim, M.S., Stanley, S.A., Murphy, K.G., Ghatei, M.A. and Bloom, S.R. 2002. The hypothalamic melanocortin system stimulates the hypothalamopituitary-adrenal axis in vitro and in vivo in male rats. Neuroendocrinology 75: 209-216.

10. Gantz, I., Konda, Y., Tashiro, T., Shimoto, Y., Miwa, H., Munzert, G., Watson, S.J., DelValle, J. and Yamada, T. 1993. Molecular cloning of a novel melanocortin receptor. J. Biol. Chem. 268: 8246-8250.

11. Gonzalez, M.I., Vaziri, S. and Wilson, C.A. 1996. Behavioral effects of alpha-MSH and MCH after central administration in the female rat. Peptides 17: 171-177.

12. Harris, R.B., Zhou, J., Shi, M., Redmann, S., Mynatt, R.L. and Ryan, D.H. 2001. Overexpression of agouti protein and stress responsiveness in mice. Physiol. Behav. 73: 599-608.

13. Huang, X.F., Han, M., South, T. and Storlien, L. 2003. Altered levels of POMC, AgRP and MC4-R mRNA expression in the hypothalamus and other parts of the limbic system of mice prone or resistant to chronic high-energy diet-induced obesity. Brain Res. 992: 9-19.
14. Huszar, D., Lynch, C.A., Fairchild-Huntress, V., Dunmore, J.H., Fang, Q., Berkemeier, L.R., Gu, W., Kesterson, R.A., Boston, B.A., Cone, R.D., Smith, F.J., Campfield, L.A., Burn, P. and Lee, F. 1997. Targeted disruption of the melanocortin-4 receptor results in obesity in mice. Cell 88: 131-141.

15. Imaki, T., Nahan, J.L., Rivier, C., Sawchenko, P.E. and Vale, W. 1991. Differential regulation of corticotropin-releasing factor mRNA in rat brain regions by glucocorticoids and stress. $J$. Neurosci. 11: 585-599.

16. Jegou, S., Yacoubi, M.E., Mounien, L., Ledent, C., Parmentier, M., Costentin, J., Vaugeois, J.M. and Vaudry, H. 2003. Adenosine $\mathrm{A} 2 \mathrm{~A}$ receptor gene disruption provokes marked changes in melanocortin content and pro-opiomelanocortin gene expression. J. Neuroendocrinology 15: 1171-1177.

17. Jingami, H., Mizuno, N., Takahashi, H., Shibahara, S., Furutani, Y., Imura, H. and Numa, S. 1985. Cloning and sequence analysis of cDNA for rat corticotropin-releasing factor precursor. FEBS Lett. 191: 63-66.

18. Kalin, N.H., Takahashi, L.K. and Chen, F.L. 1994. Restraint stress increases corticotropin-releasing hormone mRNA content in the amygdala and paraventricular nucles. Brain Res. 656: $182-186$.

19. Kishi, T., Aschkenasi, C.J., Lee, C.E., Mountjoy, K.G., Saper, C.B. and Elmquist, J.K. 2003. Expression of melanocortin 4 receptor mRNA in the central nervous system of the rat. $J$. Comp. Neurol. 457: 213-235.

20. Lu, X.Y., Barsh, G.S., Akil, H. and Watson, S.J. 2003. Interaction between $\alpha$-melanocyte-stimulating hormone and corticotropin-releasing hormone in the regulation of feeding and hypothalamo-pituitary-adrenal responses. J. Neurosci. 23: 7863-7872.

21. Nudel, U., Zakut, R., Shani, M., Neuman, S., Levy, Z. and Yaffe, D. 1983. The nucleotide sequence of the rat cytoplasmic beta-actin gene. Nucleic Acids Res. 11: 1759-1771.

22. Merlo Pich, E., Lorang, M., Yeganeh, M., Rodriguez de Fonseca, F., Raber, J., Koob, G.F. and Weiss, F. 1995. Increase of extracellular corticotropin-releasing factor-like immunoreactivity levels in the amygdala of awake rats during restraint stress and ethanol withdrawal as measured by microdialysis. $J$. Neurosci. 15: 5439-5447.

23. Sarkar, S., Legradi, G. and Lechan, R.M. 2002. Intracerebroventricular administration of $\alpha$-melanocyte stimulating hormone increases phosphorylation of CREB in TRH- and CRHproducing neurons of the hypothalamic paraventricular nucleus. Brain Res. 945: 50-59.

24. Vergoni, A.V., Bertolini, A., Wikberg, J.E. and Schioth, H.B. 1999. Selective melanocortin MC4 receptor blockage reduces immobilization stress-induced anorexia in rats. Eur. J. Pharmacol. 369: 11-15.

25. Von Frijtag, J.C., Croiset, G., Gispen, W.H., Adan, R.A. and Wiegant, V.M. 1998. The role of central melanocortin receptors in the activation of the hypothalamus-pituitary-adrenalaxis and the induction of excessive grooming. Br. J. Pharmacol. 123: 1503-1508.

26. Voisey, J., Carroll, L. and van Daal, A. 2003. Melanocortins and their receptors and antagonists. Curr. Drug Targets 4: 586-597. 